\title{
The three faces of herpes simplex epithelial keratitis: a steroid-induced situation
}

\author{
Gaurav Prakash, ${ }^{1}$ Kavitha Avadhani, ${ }^{2}$ Dhruv Srivastava ${ }^{1}$
}

${ }^{1}$ Department of Cornea and Refractive Surgery Services, NMC Specialty Hospital, Abu Dhabi, United Arab Emirates ${ }^{2}$ Uvea Services, NMC Specialty Hospital, Abu Dhabi, United Arab Emirates

\section{Correspondence to}

Dr Gaurav Prakash, drgauravprakash@gmail.com

Accepted 10 March 2015
CrossMark

To cite: Prakash $\mathrm{G}$, Avadhani K, Srivastava D. BMJ Case Rep Published online: [please include Day Month Year] doi:10.1136/ bcr-2014-209197

\section{DESCRIPTION}

A 40-year-old south Asian blue collar worker presented to us with worsening pain, photophobia and redness for 15 days in spite of taking medications.

Slit-lamp examination and fluorescein staining showed three different varieties of lesions: epithelial dots (9 o'clock), dendritic pattern (6 o'clock) and a geographic epithelial keratitis (12-2 o'clock), suggesting herpes simplex virus epithelial keratitis (figure 1). The two former lesions occur more commonly, and geographic keratitis occurs rarely due to coalescence of dendritic lesions; from either topical steroid abuse or low immunity. ${ }^{12}$ It is rare to see all these three presentations at the same time.

Review of medications confirmed the use of Prednisolone eye drops acetate, which explains the occurrence of the geographic lesion. It is often prescribed in cases of red eye to bring symptomatic relief. However, the classic recommendation is to refrain from this practice as topical steroids can worsen untreated infective keratitis, or prolong viral shedding in adenoviral conjunctivitis.

The patient was also evaluated by the internist for immunocompromised state including clinical signs of acquired immune deficiency syndrome. Serological testing for HIV infection was also performed. There were no clinical or serological features suggesting an HIV infection or other systemic immunocompromised states. It is important to note here that if the patient had displayed systemic immunocompromise, it may have been useful to

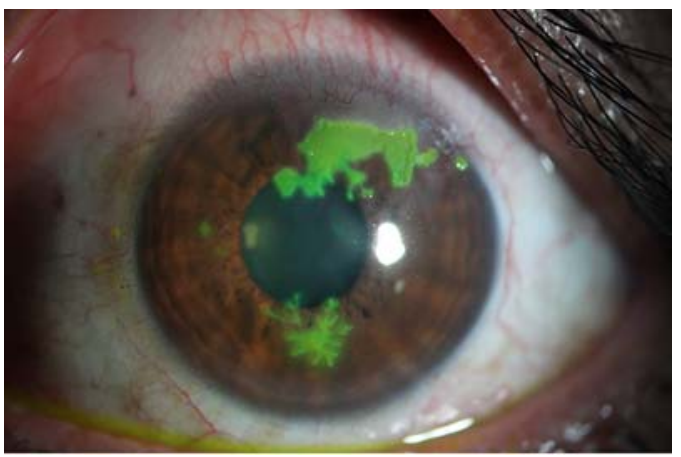

Figure 1 Slit-lamp photograph showing three phases of lesions: epithelial dots (9 o'clock), dendritic pattern (6 o'clock) and a geographic epithelial keratitis (12-2 o'clock), suggesting herpes simplex virus epithelial keratitis. add oral Aciclovir to the treatment. ${ }^{3}$ We also recommend HIV testing for all such patients.

Most cases with geographic ulcers present late with a larger ulcer. We believe that as this patient presented earlier in the disease process, all the three phases could be seen at the same time. It is likely that had he continued using the steroid, these lesions would have coalesced to form a single geographic ulcer.

Apart from being unique in that all three phases of HSV keratitis were seen together in one eye, this case also stresses the importance of avoiding steroid drops in an undiagnosed early red eye. The treatment included acyclovir eye ointment $5 \times /$ day and stopping the topical steroids.

\section{Learning points}

- Any case of undiagnosed red eye should be evaluated in detail before starting topical steroids.

- Staining the cornea with sodium fluorescein solution will highlight any epithelial lesion, which is generally a contraindication for steroid drops.

- Dendritic pattern is the most characteristic display of presentation for herpes simplex keratitis. However, the other two forms, epithelial dots and geographic ulcer can also occur and thus should be ruled out actively.

Contributors GP, KA, DS were involved in idea and design. GP, DS took part in data collection. GP and KA wrote the manuscript. GP, KA, DS critically revised the manuscript and approved the final version of the manuscript.

Competing interests None.

Patient consent Obtained.

Provenance and peer review Not commissioned; externally peer reviewed.

\section{REFERENCES}

1 Holland EJ, Schwartz GS. Classification of herpes simplex virus keratitis. Cornea 1999;18:144-54.

2 American Academy of Ophthalmology: Herpes Simplex keratitis http://one.aao.org/focalpointssnippetdetail.aspx?id=356f0d138853-410f-ac6b-7ff5e0257800 (accessed 24 Dec 204).

3 Wilhelmus KR. Antiviral treatment and other therapeutic interventions for herpes simplex virus epithelial keratitis. Cochrane Database Syst Rev 2010;(12):CD002898. 


\section{Images in...}

Copyright 2015 BMJ Publishing Group. All rights reserved. For permission to reuse any of this content visit http://group.bmj.com/group/rights-licensing/permissions.

BMJ Case Report Fellows may re-use this article for personal use and teaching without any further permission.

Become a Fellow of BMJ Case Reports today and you can:

- Submit as many cases as you like

- Enjoy fast sympathetic peer review and rapid publication of accepted articles

- Access all the published articles

- Re-use any of the published material for personal use and teaching without further permission

For information on Institutional Fellowships contact consortiasales@bmjgroup.com

Visit casereports.bmj.com for more articles like this and to become a Fellow 